\title{
Piezometric Assessment for Salinity in Multi Aquifer System in Dharoi Command Area, Gujarat
}

\author{
Hema R. Parmar, N. D. Shah, Pradeep Majumdar
}

\begin{abstract}
Our earlier study carried out in Dharoi command area in Sabarmati River Basin, in India, defined the sensitive parameters to address the problem of water logging and salinity in the shallow aquifer, contribution of multi-aquifer system in making the scenario complex, was thus evident. Therefore, extension of the study by analyzing the piezometric data of complex lithological setup is attempted in this paper. The present paper establishes and discusses the relationships of various depth wise aquifer zones with the help of the seasonal piezometric heads and TDS values, analyzed as tracers.
\end{abstract}

Key Words: Aquifer, Aquitard, piezometric head, Total dissolved solids, depth zones.

\section{INTRODUCTION}

Many factors, including topography, lithology, geological structures, porosity, slope, drainage patterns, landform, land use/ land cover, and climate, affect the occurrence and movement of groundwater in a region. Hydro-geological experiments and geophysical surveys help to explain the process of groundwater recharge in the study region. Advective transport of pollutants in a groundwater domain is governed by the flow velocity vectors. The diffusion of pollutants in groundwater is fastest in the most efficient recharge zones. Over reliance on groundwater resources lead to the over-drafting of groundwater, and causing ecological problems such as decreased groundwater levels, water exhaustion and deterioration of water quality. Numerical modelling techniques have been extensively used to define the groundwater flow vectors and contaminant transport. In some areas, the surface water and groundwater management are morecomplex for a multi aquifers condition than a single unconfined/shallow aquifer condition. The multi aquifers condition means a subsurface formation with an unconfined/shallow aquifer and one or more than one confined/deep aquifers, as well as aquitards in between aquifers. In shallow aquifers, groundwater level, the recharge rate, and the river stage could be affected by the pumping activities. As for multi aquifers, groundwaster levels in shallow and deep aquifers could mutually affect each other due to pumping activities in both types of aquifers, especially when the vertical leakance of the in

Revised Manuscript Received on October 30, 2019.

* Correspondence Author

Hema R.Parmar*, Ph.D student from Charusat University, Changa.

Dr. N. D. Shah, Principal of the School of Engineering , P.P Savani University, Gujarat, India.

Dr. Pradeep Majumdar, Expatriate Professor, Addis Ababa Science and Technology University, Addis Ababa, Ethiopia..

(C) The Authors. Published by Blue Eyes Intelligence Engineering and Sciences Publication (BEIESP). This is an open access article under the CC BY-NC-ND license (http://creativecommons.org/licenses/by-nc-nd/4.0/) between aquitard (or leaky aquifer) is not so small to neglect water movement back and forth vertically adjacent aquifers (Majumdar et al., 2009). It also means the drawdown in an aquifer is a superposed effect of the pumping activities occurred along the vertical profile. Therefore, it's generally not possible to have good estimates on pump/recharge rates in the shallow aquifer regardless of the pumping activities in underlying aquifers. The vertical groundwater flow in multiaquifer setup is discussed in Majumdar (2015). The vertical leakage in multi-aquifers setting is rarely quantified in complex settings, where the recharge zone is characterized by both diffuse and preferential flows. In such setting, conventional hydraulic or tracer-based estimation of recharge or vertical leakage is problematic, unless the effects of duality of flow regimes are considered. Somaratne et al., (2016) developed a groundwater flow model spanning the Glencoe and Nangwarry areas of the GNN recharge zone to improve understanding of vertical recharge to the multi aquifers and to assess the impact on the regional flow system using MODFLOW-2000. Population of the North Gujarat region (Figure 1)in India face the problems of fluorides and other dissolved salts in groundwater that have shown increasing trend and have exceeded the safe limit since many decades. The process of deterioration of groundwater quality continues unabated and progressively increasing proportion of the population is seen to be affected by fluorosis. Out of total of 1089 villages, 441 are reported to have more than permissible level (> $1.5 \mathrm{ppm}$ ) of fluoride. Reasons of such a polluted environment is attributed to unique gradients and/or transitions of contaminant concentration profiles, biological populations, chemistry, flow, mixing characteristics, redox potential, dissolved oxygen, organic content, and thermal properties. In addition, many unique biogeochemical processes occur in this zone that can have significant impact on the fate and transport of contaminants. Majumdar (2016) used MODFLOW-SWIFT combination for generating improved parameterization to address water logging and salinity in Dharoi command area. From this study, carried out in shallow aquifer zone, the authors believed that the major course of action in spreading the pollution has been the lithological formations of the multi-aquifer system, encouraging water logging. It is well known fact that the unconfined and perched aquifers in irrigation commands are

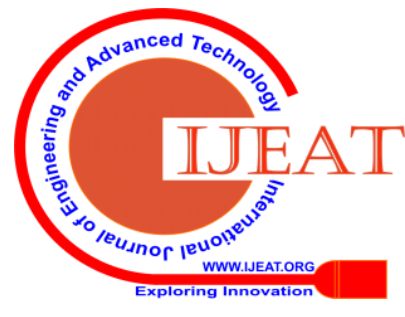


more prone to water logging and salinity problems.In-situ pollutions such as fluoride in drafted water were found to have some kind of relationship with the excessive pumping power exerted (Figure 2). Therefore, in the present paper, around 30 piezometer data in an area of 1500sq $\mathrm{km}$ have been analyzed in a depth range of 30 to $300 \mathrm{~m}$. Based upon the co-relations developed, piezometers were groupedin sensitive depth zones to define aquifers, considered to be fully penetrating. Such a method of conceptualizing a multiaquifer system would help in analyzing the lithologs of those piezometers using software such as ROCKWORKS.

\section{METHODOLOGY}

For setting out the contour: Surfer and Grapher software will use.

\section{A. Surfer}

Surfer is a full-featured 3D visualization, contour and surface modelling package that runs on Microsoft Windows. Surfers, the volume measurement readings, terrain modeling, depth modeling, landscape visualization ,surface analysis, contour maps, and 3D surface watersheds are used extensively, contour and 3D surface plots that run on many more. Surfer 9 for Microsoft Windows The program window. Surfer 9 to quickly and easily transform data into outstanding contour maps and surface plots. And with all the options available in Surfer 9,you can do exactly what you customize the map in order to produce the desired presentation. To produce publication quality maps of surfers, quickly and easily, and never more dramatically satisfying.

\section{B.Rockwork:}

RockWorks is a great tool for geotechnical and civil engineers to use when evaluating construction and excavation sites. Whether you're in the beginning, middle or ending phase of a project.

\section{Full GIS Integration}

Easily construct your grid-independent hydrogeologic conceptual model in minutes using your existing GIS data sets. Quick and easy data importing of all common file types and formats .Automatic coordinate system and units conversion on import .Automatic data validation and intelligent error checking on import .Define model boundaries, property zones ,boundary conditions and attributes from imported GIS data .Define complex geology and model layers using borehole log data and cross-sections .Interpret GIS data to define hydro geologic properties and boundaries independent of the grid behaviour of multiaquifer system, useful for knowledge base.

\section{STUDY AREA}

The irrigation command area of the right bank canal of Dharoi reservoir on Sabarmati river in Mehsana district in north Gujarat, India is located in Figure 1. The geographical area of around 9,027 km2 is rich in agricultural production but is largely dependent on groundwater, both for irrigation and drinking water requirements. Temperature in the region varies between four degree Celsius in winter to 44 degree Celsius in summer. The humidity during monsoon reaches
95\% or even more. Although annual rainfall varies between 500 to $1,500 \mathrm{~mm}$, more than $85 \%$ of it occurs during the months of July and August. Major rivers flowing through the region are Banas, Saraswati, Rupen and Sabarmati. Many of them remain dry in most parts of a year. Sandy to sandy loam type of soil is deposited in the study area. Some areas also indicate clay loam type of soil due to admixture of argillaceous matrix adequately. Thick pile of recent alluvial formation has deposited in the study area. Alternate layers of sand and clay are laid down to a considerable depth of about 180 to $330 \mathrm{~m}$. Blue clay, boulder formation and basement rock is also met with, at certain places in the study area. The thickness of alluvial formation increases from north-east to south-west. The physical observations indicate coarse sandy material laid down in the Eastern areas where as it becomes finer towards west and south-west areas. Ground water occurs under water tableas well as in confined condition in the discontinuous beds of varying thickness of sand, kankar and gravel that constitutes the alluvial aquifers in hard rock terrain. Consolidated formations are mainly dominated by basaltic lava flows associated with intertrappean, infratur appean and archean rock formation represented by phyllites, gneisses, quartzite and granites. Minerals such as Keoline and crude oil are available in the nearby areas. In the adjoining areas of Mehsana and Sabarkantha district the aquifers are highly jointed and fractured or extensively weathered. Wells tapping some thick rock-formations of this type yield as much as 1, 00,000 litres per hour and 40,000 litres per hour are more common. Aquifers of moderate potential are available within 100-150 m below GL and even as closed as at $30-40 \mathrm{~m}$ depth in some of the locations. The phreatic aquifers in the alluvial strata are only suited for shallow wells and low yields tube wells. Bradley and Phadtare (1989) highlighted two distinct aquifer systems, viz. a phreatic aquifer varying in thickness from 9 to $35 \mathrm{~m}$ overlying a series of aquifers and aquitards (Fig 3) and isolated perched aquifers (Fig 3) within the phreatic aquifer. They found that the total thickness of the aquifer system is around 250 m.Both ground water and surface water are being supplied for irrigation in the study area. Agriculture is the main non-point polluter of groundwater in irrigated areas as fertilizers and other agrochemicals are the main contaminants in the water that drains out of the root zone to contaminate the aquifer. The concentration of nitrates in the percolated water showed relation with the distributed field water and nitrogen balances over the area. Its concentration in the groundwater depended on the total recharge, pollution loading, groundwater flow and solute transport within the aquifer. The deterioration in groundwater quality almost parallels the post 1955 phase, when with the advent of tube wells and electric motors the groundwater extraction went up many folds. Groundwater depletion does not show any specific relation with fluoride concentrations in the unconfined aquifer. However, some kind of relationship could be seen between fluoride concentration and horse power used for drafting of groundwater in Fig 4.

Published By: 


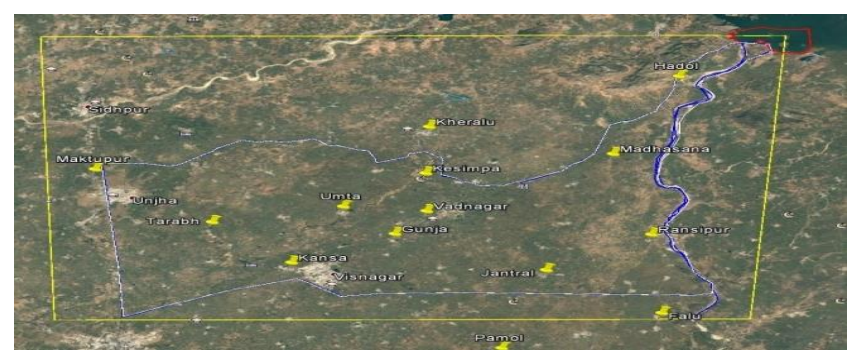

Fig 1 Study Area In Google Map

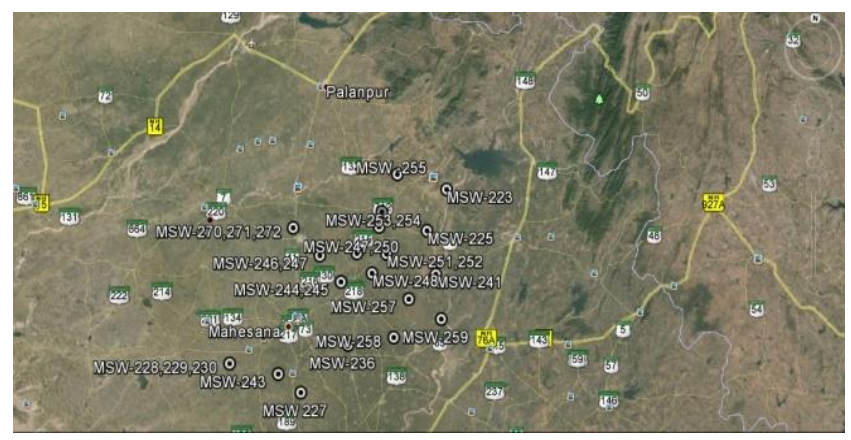

Fig 2 Piezometer Locations In The Study Area
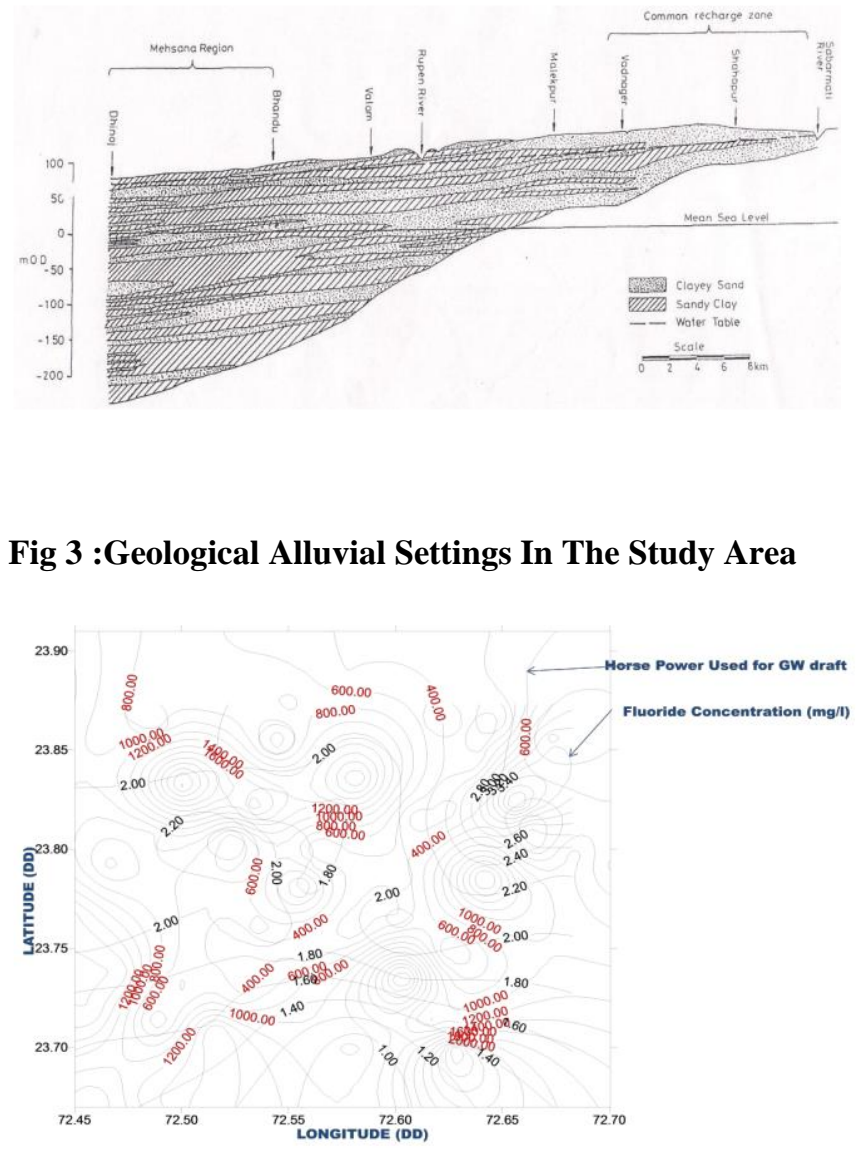
And Hp Used For Well Drafts

\section{IV.SALINITY IN MULTI-AQUIFERS:}

Analysis of seasonal groundwater level and TDS data of 29 piezometeras located in Fig 2 were carried out to conceptualize the flow and transport in the multi aquifer
Fig 3 :Geological Alluvial Settings In The Study Area

Fig 4 Relation Between Fluoride Concentration In Mg/L

system. The TDS values for May and October in the years 2000, 2005, 2010 and 2015 are scattered in figure 5in respect of the respective depths of the piezometers. of the concentration could beleakage from the shallow unconfined aquifer, spreading downward through aquitards and it's discontinuities at different locations. Fig 5 shows that the vertical movement of water is finally stopped by a continuous barrier between 50 to $100 \mathrm{~m}$ depth zone. Critically saline zones are 0 to $50 \mathrm{~m}$ and 100 to $150 \mathrm{~m}$, rest of the zones are gradually catching up to become critical. On the time scale, in general May values are more than the previous and current year's October values. This indicates that there are dissolution effects of rain between May to October and concentrations are increasing once dry season arrives. Fig 6 scatters only May TDS values, which can be considered under steady state groundwater condition. Indications are the same as previously explained, but in more specific terms, around $40 \mathrm{~m}$ depth, shallow aquifer zone separates itself. In middle aquifer zone, geologic formation at a depth around $120 \mathrm{~m}$ causing concerns for groundwater draft. Reasons for high TDS values in 0-50 m and 100-150 m may be different, upper zone may be getting polluted with surficial activities and water from 100-150 m zone may be dragging in situ material due to excessive pumping.

\section{A. Piezometric Heads in Multi Aquifer}

To further investigate the hydraulics of the multi-aquifer system, in the region, depths to water level in the piezometers were plotted against the total depth of the piezometers in Fig7. In shallow aquifer zone $(<50 \mathrm{~m})$ the piezometric heads fluctuated to the order of $35 \mathrm{~m}$ since the year 2000 to 2015, whereas in the middle aquifer zone (@ $120 \mathrm{~m}$ ) these pressure heads were found to have excessive fluctuations in the range of $100 \mathrm{~m}$. This is interesting observation in respect of the amount of pumped water and power being applied in the middle zone. In rest of the piezometers, head fluctuated between a depth range of 10-12 $\mathrm{m}$ in entire 15 years, which is very normal.

\section{B. Pressure-Concentration Relationship}

In the present paper seasonal TDS values have been analyzed, presuming it to be natural isotopes, have some kind of relationships with the hydraulics of groundwater flow in the multi-aquifer domain. In Fig 8, head rise in the piezo meters from May to October in the various monsoon seasons has been shown as per the depth ranges. As the measurements were taken from the top, negative values are the head rises, quite a few positive values depict the fall in the piezo metric heads. These are actually pressure head fluctuations mainly attributed to the drafts from the bore wells. general, bore well drafts remain minimum while surface or shallow water are being explored during the monsoon and immediately after post monsoon periods, except in those times when monsoon is erratic. One can easily visualize that these fluctuations are not same in all the piezometers in the same year in spite of same cropping pattern and monsoon effects in the entire region. Does that mean confined aquifers at different depths are operative under different boundary pressures? It is unlikely in $300 \mathrm{~m}$ depth, unless the separating aquitards are active and approaching an aquiclude or aquifuge at locations.

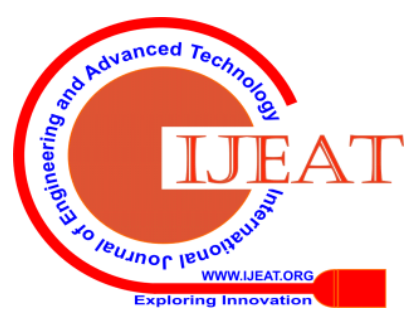


Piezometric Assessment for Salinity in Multi Aquifer System in Dharoi Command Area, Gujarat

Indications of these abnormal fluctuations restrict us to consider any of these piezometers perfectly in a confined state, may be better suited to a semi-confined state, where leakage from the overlying and underlying aquitard together with nonuse or extent of use of bore wells during the monsoon transforming the aquifer from a unconfined to a confined state. Fig 9 has been presented to further elaborate the typical concerns of the multi aquifer system in question. We tried to put the seasonal head fluctuations in different piezometers in a random variable mode and find out the most sensitive zones of fluctuations. It is evident from fig 9 that the zone between depths 109.6 to $189.6 \mathrm{~m}$ is experiencing biggest pressure variations to the order of $13 \mathrm{~m}$ with an expectancy of $90 \%$ probability of occurrences followed by the zone between 29.6 to $109.6 \mathrm{~m}$ with a probability of occurrences of $85 \%$. Rest the two zones falling between 189.6 to 349.6 are comparatively calmer, not yet drilled that much. Similarly, while analyzing the TDS fluctuations, Fig 10 is presented to uphold the view that depth zones 0-50 m and then 100-150 m are vulnerable in respect of contaminant migration and it's dissolution. Again, specifically in 100-150 m zone, how concentration is getting marginalized is a big question. Does it because of the dissolution process or precipitation of suspended and dissolved chemicals in a comparatively static condition due to less exploitation. Further elaboration could be seen in Fig 11 where head and respective concentration fluctuations are plotted. Possibility of best fits is evident, omitting 3-4 points. Therefore, a relationship between the head rise and TDS variation in a particular season may not be completely over ruled. Such relationship in a confined aquifer is not common, and indicative of a semi confined state. Such information is vital as input to groundwater modelling exercises. Once the paper has already highlighted depth wise the two most sensitive zones having different hydraulic governance, it would be obvious to compare the concentration variation in them. These are included in Fig 12. Relationship between pressure and concentration variation is similar in both the depth zones.

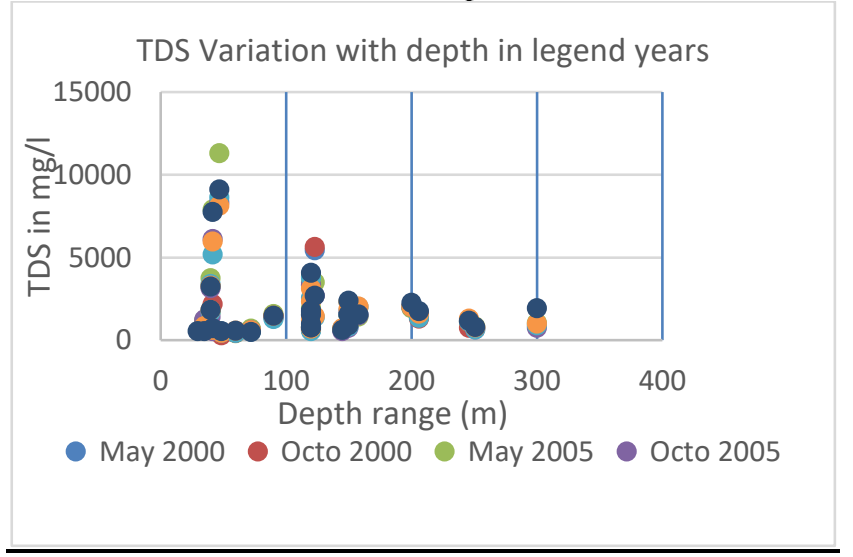

Fig 5 Depth wise seasonal TDS Variation

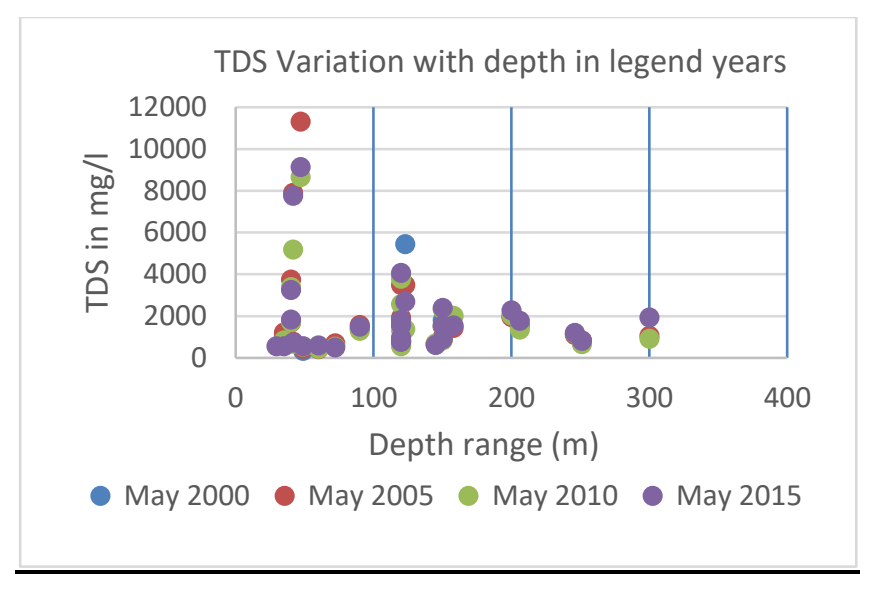

Fig 6Depth wise Pre-monsoon TDS Variation

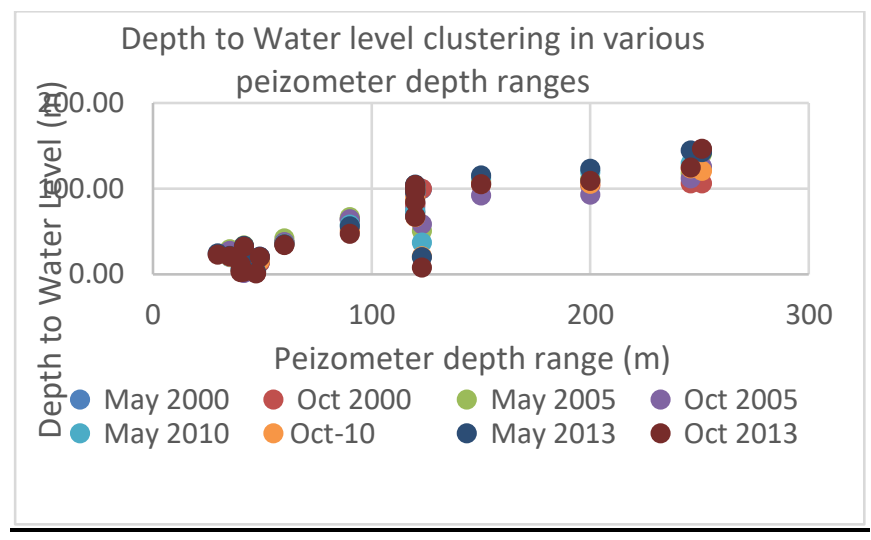

Fig 7 Pre and Post monsoon draw downs in different depths

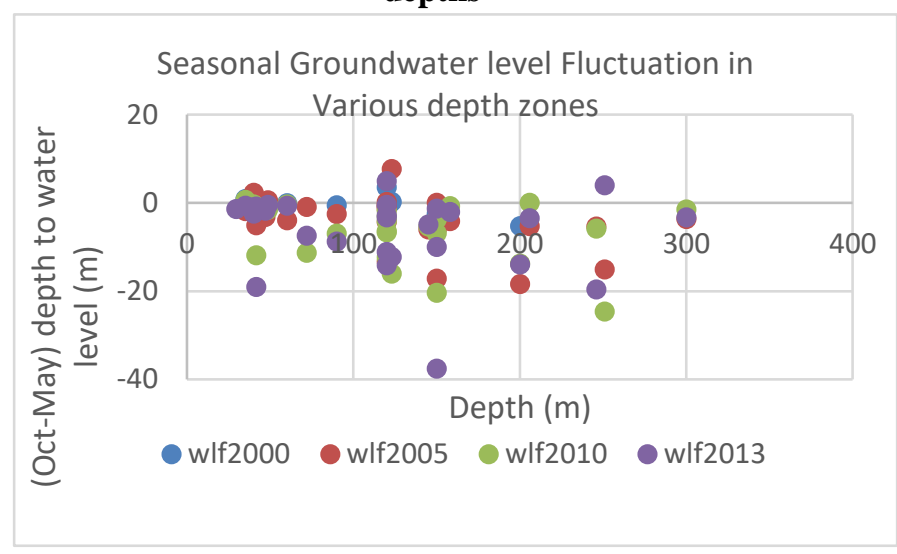

Fig 8 Seasonal Groundwater level Fluctuations in various depth zones 
Probability of Seasonal Groundwater Fluctuation in Various depth zones

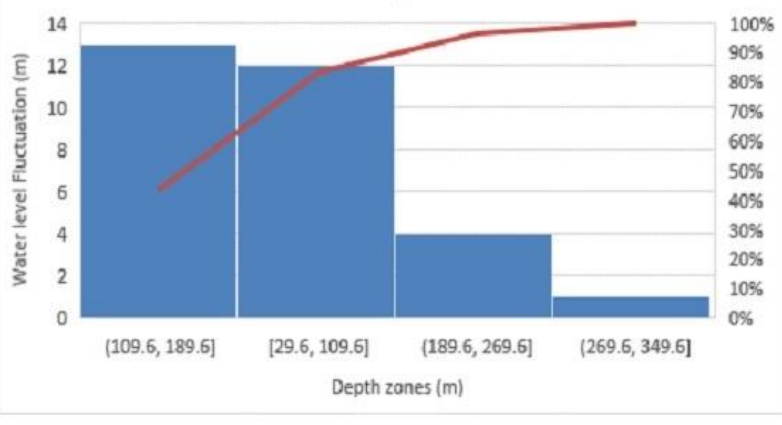

Fig 9 Most sensitive head fluctuation zones in Sabarmati multi-aquifer system

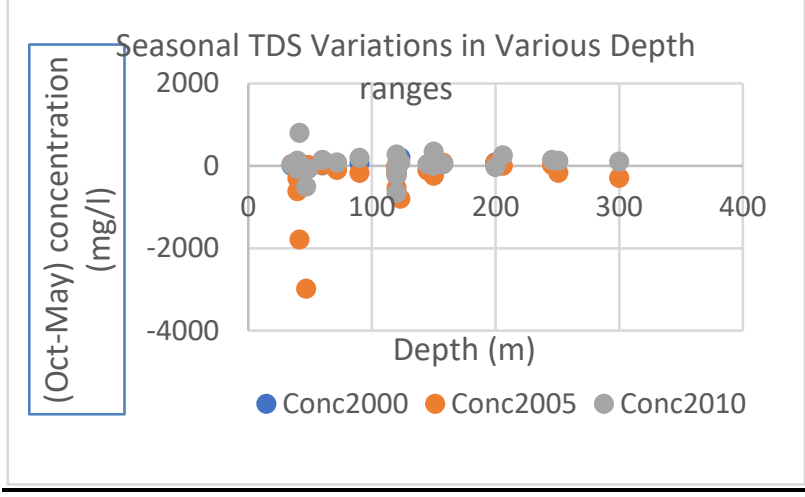

Fig 10 Seasonal TDS variations in different depth zones

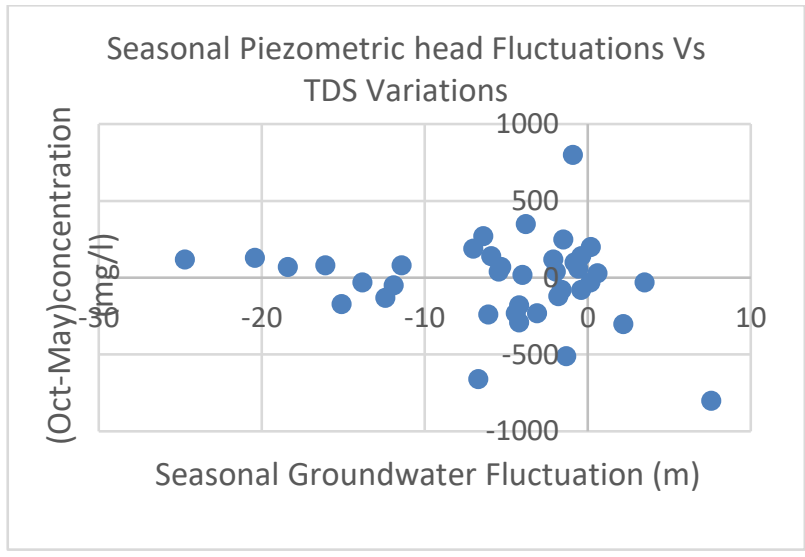

Fig 11 Relation between Seasonal head fluctuation and TDS variation

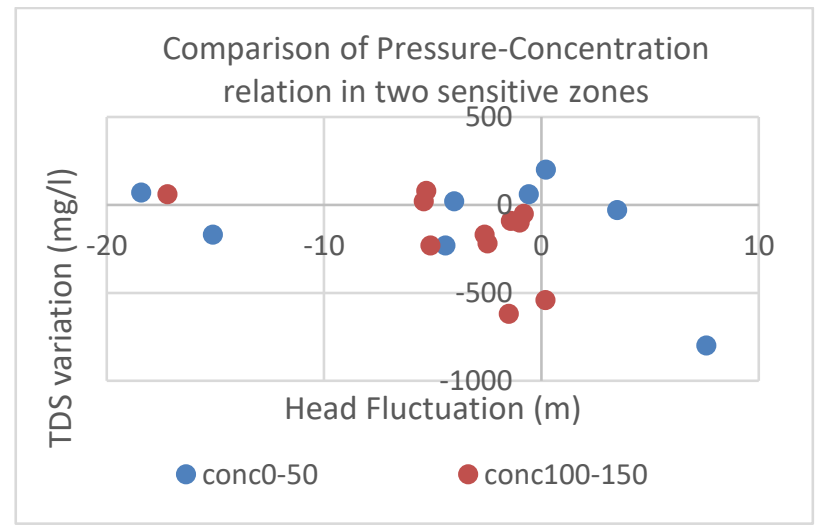

Retrieval Number F8246088619/2019@BEIESP

Authors deeply acknowledge the Geo-referencing support provided by Prof N.D .Shah of Savani Institute , Surat, Ahmedabad, and Dr. P. K. Majumdar , Expatriate Professor, Addis Ababa Science and Technology University, Addis Ababa, Ethiopia

Analysis of piezometric data, is carried out to understand the pressure and concentration behaviour in the parts of multiaquifer of Sabarmati river basin in North Gujarat in India. Existence of semi-confined aquifers are concluded based upon the head fluctuations and concentration variations. In respect of the head fluctuation two sensitive zones are found, although relation with TDS variation is evaluated as identical in both the zones. Such information is useful while setting up the lithology correlations and carrying out groundwater modelling exercises.

\section{ACKNOWLEDGEMENTS:} \& Sciences Publication 


\section{Piezometric Assessment for Salinity in Multi Aquifer System in Dharoi Command Area, Gujarat}

\section{REFERENCES:}

1. Bradley, E and Phadtare, P.N. (1989), Paleohydrology affecting recharge to overexploited semiconfined aquifers in the Mehsana area, Gujarat State, India, Journal of Hydrology, Vol: 108, Issue: C, Page: 309-322

2. Y.K.Kai (2014),Application of an integrated surface watergroundwater model to multi-aquifers modeling in Choushui River alluvial Taiwan, Hydrological Processes, Volume28, Issue3, January 2014, Pages 1409-1421

3. N.B Kavalannekar, S.C. Sharma, and K.R.Rushton (1992), Overexploitation of an alluvial aquifer in Gujarat, India, J. Hydrological Sciences, 37(4), 329-346.

4. P.K .Majumdar ,G.C.Mishra , M.Sekhar \& K.Sridharan. (2009),Coupled Analytical Solutions for Forced Well Recharge in Confined Aquifers, ASCE J. Hydrological Engineering, 14(12), 2009, 1351-1358.

5. P.K .Majumdar. (2015),Multi-Aquifer Parameterization with well loss in Vertical Flows, Journal of Water Resource and Hydraulic Engineering, Jan. 2015, Vol. 4, Iss. 1, PP. 9-22

6. P.K .Majumdar (2016), Improved model application for water-logging and salinity in command areas', Int. J. Society Systems Science, 2016, Vol. 8, No. 3, pp.256-288.

7. N.Somaratne, J.Lawson, and S.Mustafa, (2016) A Heuristic Approach to Estimating Spatial Variability of Vertical Leakage in the Recharge Zone of the Gambier Basin Tertiary Confined Sand Aquifer, South Australia. Journal of Water Resource and Protection, 8, 183-200. http://dx.doi.org/10.4236/jwarp.2016.82015

8. Y.H.L, C H.J.Chu (2010). Understanding space-time patterns of groundwater system by empirical orthogonal functions: A case study in the Choushui River alluvial fan, Taiwan. Journal of Hydrology 381: 239-247.

9. W.C Hung, C. Hwang, C.P Chang, J..Y.Yen, C.H Liu, W.HYang (2010)Monitoring severe aquifer-system compaction and land subsidence in Taiwan using multiple sensors: Yunlin, the southern Choushui River Alluvial Fan, Environ Earth Sci (2010) 59:1535-1548 DOI 10.1007/s12665-009-0139-9.

\section{AUTHORS PROFILE}

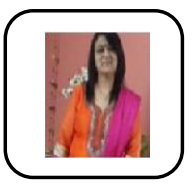

Education: M.E. (WRE) From L.D Engineering, Gujarat University, PHD Persuing.

\section{Publications:}

1.Setting of co-relation in Hydro-geology in Sabarmati Basin,Gujarat,India.Hema R. Parmar, Dr. N.D.Shah, Dr.P.K.Majumdar,Paper present and Published in ,The Third Intl. Conf. On Advances in Civil, Structural and Mechanical Engineering - ACSM 2015 ,at Bangkok,Institute of Research Engineers and Doctors, USA .All rights reserved.ISBN: 978-1-63248-083-5 doi: 10.15224/ 978-1-63248-083-5-65.

2. Establishe co-relation of Hydro Gyological by rockworks in Command Area. Hema R. Parmar2, Dr.N.D.Shah2,Dr. P.K.Majumdar3International Journal of Scientific Research ,Volume 8, Issue 4,April 2017. ISSN 22295518(UGC Journal)

3. Model Application for salinity in Command Area.Hema R. Parmar 1, Dr.N.D.Shah2,Dr. P.K.Majumdar., IOSR Journal of Mechanical and Civil Engineering (IOSR-JMCE) e-ISSN: 2278-1684,p-ISSN: 2320-334X, Volume 14, Issue 3 Ver. I (May. - June. 2017), PP 01-11 www.iosrjournals.org(UGC Journal)

4. A Study Of Ground Water Modeling For Shallow Aquifer , In Gandhinagar District, Gujarat ,BY

1. Hema R. Parmar 2. Dr.N.D.Shah, 3. Dr. P.K.Majumdar

International Journal of Technical Innovation in Modern Engineering \& Science (IJTIMES) Impact Factor: 3.45 (SJIF-2015), e-ISSN: 2455-2584 Volume 3, Issue 06, June-2017(UGC Journal)

5.Study of Ground water condition in multi Aquifer in Dharoi Command Area By GIS and Rockworks,

1Hema R. Parmar, 2Dr.N.D.Shah, 3Dr. P.K.Majumdar

International Journal of Scientific Research and Review,Volume 7, Issue 3, 2018,ISSN NO: 2279-543X(UGC Journal)

6. Model Application to Solve Salinity Problems in Study Area of Sabarmati River Basin in Gujarat, India.

1. Hema R. Parmar 2. Dr.N.D.Shah, 3. Dr. P.K.Majumdar

Paper present and Published in,International conference ,Hydro-2017 International, L.D. College of Engineering Ahmedabad, India

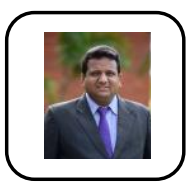

Education: Ph.D. in Civil-Structural Engineering fromSVNIT, Surat

Dr. Niraj D Shah is the Principal of the School of Engineering in P. P. Savani UniversityDr. Shah has an experience of 22 years including academic, administrative, industrial and research experience. He has several publications, authored books, guided Doctoral and P.G students and has been honored with numerous prestigious awards. Dr. Shah has consulted in various projects. He has been invited to deliver several key note/ plenary/ expert lectures and to present scientific papers in several international and national conferences in India and abroad. He has travelled across the world and represented India globally.

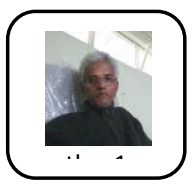

Education, $\mathrm{PhD}$, Indian Institute of Science, Bangalore, India .

Books: More than 20 books

Projects

1.From 12/1998 to 07/2003, Study of Artificial Recharge in Maharashtra. , World Bank Project encompassing study of 3 specific sites in Ozhar, Bamnod and Baramati in Maharashtra 2. 12/1998 to 07/2003, Study of Artificial Recharge in Maharashtra. World Bank Project encompassing study of 3 specific sites in Ozhar, Bamnod and Baramati in Maharahtra.

3.From 12/1998 to 07/2003, Fresh water Saline water interrelationships in the multi- aquifer system of Krishna Delta in coastal Andhra Pradesh. World Bank Project for developing numerical model in Krishna Delta in Andhra Pradesh

4.From $07 / 2003$ to $12 / 2004$, Groundwater modelling in central Punjab under Information Technology for Sustainable Agriculture in Punjab (ITSAP) , UNDP and TIFAC, DST sponcered Project to understand depleting water table conditions

5.From 01/1997 to 04/1997, Conceptual Design for Water supply systems Package 1 Villages of Ron and Nargund Taluks in Dharwad. , Neetherland Assisted Project to provide domestic water to water scarce villages

6.From 01/2004 to 04/2004, Environmental Impact Assessment of a secured Landfill in Ankaleshwar, Gujarat, Concultancy based project eased by Bharuch Enviro Infrastructure Ltd., Ankaleshwar and National Productivity Council, New Delhi to assess the risk and the uncertainties involved in leachate migration to groundwater

7.From 07/2007 to 06/2008, Seepage estimation in Jaswantsagar project, Jodhpur, Govt of Rajasthan, India forwarded project to analyse the reasons for increase in seepage flow.

\section{Journal Articles}

1.P. K. Majumdar, N. C. Ghosh \& B. Chakravorty, Analysis of Arsenic Contaminated Groundwater Domain in Nadia District of West Bengal, Journal of Hydrological Sciences, 47S, August 2002, S55-S66.

2.P. K. Majumdar, M. Sekhar, K. Sridharan \& G. C. Mishra, Numerical simulation of groundwater flow with gradually increasing heterogeneity due to clogging, Journal of Irrigation and Drainage Engineering, Vol. 134, No. 3, May/June 2008, pp. 400-404

3.P. K. Majumdar, G. C. Mishra, M. Sekhar \& K. Sridharan, Coupled Analytical Solutions for Forced Well Recharge in Confined Aquifers, ASCE J. Hydrological Engineering , 14(12), 2009, 1351-1358.4.P. K. Majumdar, S. Ram \& P. R. Rao, Artificial Recharge in multi aquifers of a mountainous watershed, ASCE J. Hydrological Engineering, 14(3), 2009, 215-222

5.G. C. Mishra \& P. K. Majumdar, Unsteady Solution for Well Recharge in A Low Diffusive Aquifer, J. Irrigation and drainage, ASCE, Vol. 136, No. 12, December, 2010

6.P. K. Majumdar, Modeling of Coastal Hydrogeology in Krishna Delta of Southern India, Int. J. Society Systems Science, Vol. 2, No. 4, 2010, 351 374

7.P. K. Majumdar, Sustainability of Societal Water Management Practices, Int. J. Society Systems Science, Vol. 5, No.2, 2013, 113-135.

8.P. K. Majumdar, K. Sridharan,G. C. Mishra, M. Sekhar, Unsteady Equation for Free Recharge in a Confined Aquifer, Journal of Geology and Mining Research Vol. 5, No. 5, May 2013, 114-123.

9.P. K. Majumdar and S Ram, Source and Impact assessment of artificial recharge in water scarce interfaced multi-formation, International Journal of Advanced Research, Volume 1, Issue 4, 2013, 83-91 
9.P. K. Majumdar, New Dimensions in Reservoir Sedimentation, Lakes and Reservoirs: Research and Management 2015 20: 1-12

10.N. Yoganarsimhan \& P. K. Majumdar "Graphic Aided Design of Minor Irrigation Scheme in Saurashtra Region of Gujarat"; Navnirman, JulyDecember 1990.

11.P. K. Majumdar, P. V. Seethapathy \& B. K. Purandare, "Groundwater Pollution in Palar River Basin, Tamilnadu"; Journal of AHI,Vol.IX, No.3\&4,1996 and communication paper in Golden jubilee session of Central Board of Irrigation and Power, New Delhi, September 1995.

12.P. K. Majumdar \& P. V. Seethapathy, "State of Art for Groundwater Quality Modelling", published in the Journal of Indian Society of Hydraulics, September-October 1996, Vol 2 No 2.

15.P. K. Majumdar, Improved Conceptual Development for water-logging and salinity in Irrigation Command, Under review in Int Journal for Society System Science publication.

16.P. K. Majumdar, Multi-Aquifer Parameterization with well loss in Vertical Flows, Journal of Water Resource and Hydraulic Engineering, Jan. 2015, Vol. 4, Iss. 1, PP. 9-22 